\title{
Production of biossurfactants using soybean meal andrice husk with Bacillus amyloliquefaciens mo- 04b bysolid state fermentation (ssf)
}

\author{
Juliana Massi", Doumit Camilios Neto, Maria Inês Rezende \\ From 5th Congress of the Brazilian Biotechnology Society (SBBIOTEC) \\ Florianópolis, Brazil. 10-14 November 2013
}

The biosurfactants are produced by various microorganisms and comprise a diversity of molecules characterized by low toxicity, high biodegradability and potential substitutes for synthetic surfactants that cause environmental impact. The southern region of Brazil has an agricultural based economy that produces large volumes of solid-waste per year. These solid-wastes must be properly treated and/ or disposed. Alternatively, biotechnological strategies of use or re-use these solid-wastes have been applied aiming the production of metabolites with economic value. Given that, the production of biosurfactants by solid-state fermentation using agricultural-waste as substrates seems to be a promising option to decrease biosurfactant production costs. The goal of this study was to avaluate the capacity of production biosurfactants by Bacillus amyloliquefaciens $\mathrm{MO}-04 \mathrm{~B}$ in solid state fermentation (FES), isolated from soil contaminated by oil collected near to the Getúlio Vargas Refinery-PR (PR-REPAR) and characterized as a producer of surfactin by submerged fermentation. The cultures were developed in $250 \mathrm{~mL}$ Erlenmeyer flasks containing soybean mean and rice husk $3: 1 \mathrm{~g}$ (w/w), dampened with a solution of salts $\left(3 \mathrm{~g} / \mathrm{L} \mathrm{KH}_{2} \mathrm{PO}_{4}\right.$, $7 \mathrm{~g} / \mathrm{L} \mathrm{K}_{2} \mathrm{HPO}_{4}, 0.2 \mathrm{~g} / \mathrm{L} \mathrm{MgSO}_{4} \cdot 7 \mathrm{H}_{2} \mathrm{O} ; 1 \mathrm{~g} / \mathrm{L}\left(\mathrm{NH}_{4}\right)_{2} \mathrm{SO}_{4}$, giving $80 \%$ moisture; inoculated with $1 \mathrm{~mL}$ of cell suspension $\left(4.10^{8} \mathrm{CFU} / \mathrm{mL}\right)$ and incubated at $30 \pm 2^{\circ} \mathrm{C}$ for $30 \mathrm{~h}$. The disruption was by adding $50 \mathrm{~mL}$ of distilled water content homogenised at $180 \mathrm{rpm}$ for $30 \mathrm{~min}$, and centrifuged at $10,000 \mathrm{rpm}, 20 \mathrm{~min} ., 4 \pm 2^{\circ} \mathrm{C}$. In the supernatant were recovered by precipitation biosurfactants $(6 \mathrm{M} \mathrm{HCl}$, $\mathrm{pH}$ 2) $4 \pm 2{ }^{\circ} \mathrm{C}$ (overnigth) and extracted with dichloromethane. The sample was resuspended in water, neutralized (0.5 M NaOH, $\mathrm{pH}$ 7) and lyophilized. The performance of biosurfactants was $33 \mathrm{mg} / \mathrm{GDS}$ were

Universidade Estadual de Londrina, Londrina, PR, Brazil solubilized in determining the emulsification index $\left(\mathrm{IE}_{24}\right)$ equal to $62.5 \%$ and the lowering of surface tension (ST) which was $39.6 \mathrm{mN} / \mathrm{m}$. Thus Bacillus amyloliquefaciens MO-04b produced biosurfactants (lipopeptides/surfactin) by solid state fermentation substrates using soybean meal and rice husk as substrates. Futher studies will be developed to optimize the production of biosurfactants using factorial design and analysis by response surface methodology.

Published: 1 October 2014

doi:10.1186/1753-6561-8-S4-P223

Cite this article as: Massi et al:: Production of biossurfactants using soybean meal andrice husk with Bacillus amyloliquefaciens mo-04b bysolid state fermentation (ssf). BMC Proceedings 2014 8(Suppl 4):P223.

Submit your next manuscript to BioMed Central and take full advantage of:

- Convenient online submission

- Thorough peer review

- No space constraints or color figure charges

- Immediate publication on acceptance

- Inclusion in PubMed, CAS, Scopus and Google Scholar

- Research which is freely available for redistribution 